\title{
Development of Viral Vectors Based on Citrus leaf blotch virus to Express Foreign Proteins or Analyze Gene Function in Citrus Plants
}

\author{
Jesús Agüero, Susana Ruiz-Ruiz, María del Carmen Vives, Karelia Velázquez, Luis Navarro, \\ Leandro Peña, Pedro Moreno, and José Guerri
}

Centro de Protección Vegetal y Biotecnología, Instituto Valenciano de Investigaciones Agrarias (IVIA), Ctra. MoncadaNáquera Km. 4.5, Moncada, 46113 Valencia, Spain

Submitted 23 February 2012. Accepted 30 May 2012.

\begin{abstract}
Viral vectors have been used to express foreign proteins in plants or to silence endogenous genes. This methodology could be appropriate for citrus plants that have long juvenile periods and adult plants that are difficult to transform. We developed viral vectors based on Citrus leaf blotch virus (CLBV) by duplicating a minimum promoter ( 92 bp) either at the $3^{\prime}$ untranslated region (clbv3 $\mathrm{pr}$ vector) or at the intergenic region between the movement and coat protein (CP) genes (clbvINpr vector). The duplicated fragment $(-42 /$ $+50)$ around the transcription start site of the $C P$ subgenomic RNA (sgRNA) had the full promoter activity and induced synthesis of a new sgRNA in infected plants. Agroinoculation with these vectors resulted in systemic infection of Nicotiana benthamiana and the resulting virions systemically infected citrus plants. A clbvINpr vector carrying the green fluorescent protein (GFP) gene expressed GFP in citrus plants and triggered $g f p$ silencing in $g f p$-transgenic citrus plants, and vectors carrying fragments of the phytoene desaturase or the magnesium chelatase genes incited a silencing phenotype in citrus plants. These silenced phenotypes persisted in successive flushes. Because CLBV infections are symptomless in most citrus species, the effective silencing induced by CLBV-derived vectors will be helpful to analyze citrus gene function.
\end{abstract}

Viral vectors have been used to express valuable proteins in plants (Gleba et al. 2007; Lico et al. 2008; Pogue et al. 2002; Valentine et al. 2007) but they can also be a helpful tool to study the function of host genes by reverse genetics. When a viral vector carries a sequence of an endogenous plant gene, virus infection triggers degradation of the cognate plant mRNA through a homology-dependent RNA degradation mechanism known as virus-induced gene silencing (VIGS) that results in a loss of function phenotype of the host (Ruiz et al. 1998). VIGS technology has been used to knock down expression of either transgenes or endogenous genes in reverse genetic studies of a variety of plant biology processes (Becker and Lange 2010; Burch-Smith et al. 2004; Purkayastha and Dasgupta 2009; Robertson 2004).

Corresponding author: José Guerri; Telephone.: +34 96342 4068; Fax: +34 96342 4001; E-mail: jguerri@ivia.es

* The $\boldsymbol{e}$-Xtra logo stands for "electronic extra" and indicates that one supplementary table is published online and that Figures 3, 5, and 6 appear in color online.
Citrus is a major commodity in fruit crop production in the world. The complex reproductive biology of citrus trees due to apomixis and sexual incompatibility between varieties, long juvenile period (often more than six years), and lack of knowledge of genes regulating different functions have hindered genetic improvement by traditional breeding methods. This might be speeded up by genomic approaches aimed at identifying genes responsible for relevant agronomic characteristics that could be used for genetic transformation or as molecular markers in conventional breeding programs. In the last few years, genome-wide expressed sequence tag (EST) collections have been generated (Forment et al. 2005) and microarray analysis has been used to identify gene-expression patterns in different tissues or at different developmental stages (Agustí et al. 2008; Alós et al. 2008; Cercós et al. 2006; Huerta et al. 2008), in various genotypes (Ancillo et al. 2007; Aprile et al. 2011), or in response to abiotic or biotic stress situations (Boava et al. 2011; Gandía et al. 2007; Gimeno et al. 2009). Availability of sequences and gene-expression patterns may help identify candidate genes potentially involved in a particular biological process; however, further analyses are required to associate each gene with a specific phenotype or biological function, the basic information necessary for any improvement program. Although confirmation of gene function often requires extensive genetic screening or costly experiments of plant transformation and transgenic line characterization, this process can be simplified by the use of VIGS. The use of viral vectors to evaluate plant gene functions is particularly attractive for woody species such as citrus, in which analysis of certain traits like flowering and fruiting by conventional breeding is hampered by their long juvenile period, and genetic transformation of adult plants is difficult (Cervera et al. 2008).

Citrus leaf blotch virus (CLBV), the type member of the genus Citrivirus, family Betaflexiviridae (Adams et al. 2012; Martelli et al. 2007), has filamentous virions approximately 960 by $14 \mathrm{~nm}$ in size. Virions are composed of a single-stranded, positive-sense genomic RNA (gRNA) of 8,747 nucleotides (nt) and a 41-kDa coat protein (CP) (Galipienso et al. 2001; Vives et al. 2001). The CLBV gRNA has three open reading frames (ORF) and untranslated regions (UTR) at the $5^{\prime}(73 \mathrm{nt})$ and $3^{\prime}$ (541 nt) ends. ORF 1, encoding an approximately 227-kDa polyprotein with methyl-transferase, AlkB-like, OTu-like peptidase, papain-like protease, helicase, and RNA-dependent RNA polymerase motifs, is translated directly from the gRNA. ORF 2, encoding an approximately $40-\mathrm{kDa}$ protein with a motif characteristic of cell-to-cell movement proteins (MPs) of the $30 \mathrm{~K}$ superfamily, and ORF 3 , encoding the $\mathrm{CP}$, are trans- 
lated from two 3' co-terminal subgenomic RNAs (MP sgRNA and CP sgRNA, respectively). ORF 2 and ORF 3 are separated by a 64-nt intergenic region (Renovell et al. 2010; Vives et al. 2001, 2002a).

The objective of this work was to develop efficient and stable CLBV-based viral vectors for either gene silencing or protein expression that could be used to identify gene functions helpful for citrus genetic improvement. We developed different viral vectors by engineering a $P m l \mathrm{I}$ restriction site at two different positions in the CLBV gRNA: at the 3' UTR downstream of the stop codon of the $\mathrm{CP}$ gene, or at the intergenic region between the MP and the CP ORF. For this purpose, we used a full-length cDNA clone of the CLBV genome (CLBVIC) that was shown to be infectious upon agroinoculation to Nicotiana benthamiana or citrus plants (Vives et al. 2008a). We also duplicated a minimum 92-bp promoter derived from the native promoter of the $\mathrm{CP}$ sgRNA in both cloning sites to express foreign genes or gene fragments by formation of new sgRNAs. In the $3^{\prime}$ UTR position, transcription of the new sgRNA was induced by the duplicated promoter whereas, in the MP-CP intergenic region, transcription of the new sgRNA was induced by the native promoter of the $\mathrm{CP}$ sgRNA and $\mathrm{CP}$ expression was controlled by the duplicated promoter. The efficiency and stability of these vectors was assessed by inserting the green fluorescent protein (GFP) gene or fragments of the phytoene desaturase ( $p d s)$, a magnesium chelatase subunit (su) or $g f p$ genes in the corresponding cloning site, agroinoculating $N$. benthamiana plants with the new constructs and using the virions produced in this host to slash inoculate citrus plants. Although constructs carrying the $p d s$ or $s u$ fragments triggered RNA silencing of the cognate genes and incited a silencing phenotype in normal citrus tissues, the vectors carrying $g f p$ or fragments thereof incited loss of fluorescence in GFP-expressing transgenic citrus plants.

\section{RESULTS}

\section{Infectivity of CLBV-based vectors.}

Although citrus is the natural host of CLBV, this virus also infects $N$. benthamiana plants, thus enabling use of this herbaceous host for preliminary testing of the efficiency and stability of CLBV-based vectors before their application on citrus plants. Using CLBV as viral vector requires insertion of foreign sequences into the CLBV genome at positions that do not compromise viral infectivity. We first tried to insert these sequences at the $3^{\prime}$ UTR immediately downstream of the CP gene and, for this purpose, a unique $P m l$ r restriction site was added just after the stop codon of the ORF 3 in the CLBV-IC clone to create the clbv3' vector. Real-time reverse-transcriptase polymerase chain reaction (RT-PCR) analysis (Ruiz-Ruiz et al. 2009) of $N$. benthamiana plants agroinoculated with this construct showed that CLBV gRNA accumulation was similar to that observed in plants agroinoculated with the CLBV-IC clone (hereafter referred to as wild type [WT]), indicating that insertion of a PmlI restriction site at this position did not affect viral infectivity.

In order to obtain a viral vector able to express foreign genes efficiently, a duplicate of the CP sgRNA promoter was inserted at the PmlI site of $c l b v 3^{\prime}$. Previously, we mapped the $5^{\prime}$ end of the CP sgRNA at position 6,831 of the gRNA, 284 nt upstream of the start codon of the CP gene (Vives et al. 2002a), and delimited boundaries of the CP sgRNA promoter in its natural context at positions -67 and +50 around the transcription start site (+1) (Renovell et al. 2010). To further confirm these results and determine the minimal sequence able to promote RNA transcription in the new genomic context, we cloned fragments of different sizes around the transcription start site of the CP sgRNA into the PmlI site of $c l b v 3^{\prime}$, keeping a new PmlI site downstream of the duplicated promoter. Then, a 154-nt fragment of the $g f p$ gene was inserted into the new $P m l$ I restriction site of each construct (Fig. 1A). In a first group of constructs, the $5^{\prime}$ boundary of the duplicated promoter was mapped using a constant $3^{\prime}$ terminus at position +284 and variable $5^{\prime}$ termini between positions -136 and -25 (Fig 1B, left panel). These potential promoter sequences were PCR amplified from the clone CLBV-IC using appropriate primers, cloned into the $P m l \mathrm{I}$ site of $c l b v 3^{\prime}$, and, after adding the $g f p$ fragment (Fig. 1A), the new vectors were agroinoculated in $N$. benthamiana leaves. At 16 days postinoculation (dpi), Northern blot analysis of total RNA (RNAt), using a digoxigenin (DIG) riboprobe specific for the CLBV 3' UTR, revealed the presence of a new $3^{\prime}$ co-terminal sgRNA of the expected size in leaves agroinoculated with vectors containing duplicated promoter fragments with their $5^{\prime}$ terminus between positions -136 and -42 but not in leaves agroinoculated with the vector carrying the $-25 /+284$ duplicated promoter (Fig. 1B, left panel). Therefore, the $5^{\prime}$ boundary of a fully active CP sgRNA promoter in the new genomic context was located between positions -42 and -25 upstream of the transcription start site. Due to the location of the inserted fragments, the gRNA and the two natural sgRNAs (MP sgRNA and CP sgRNA) showed increased size in comparison with the cognate molecules in leaves agroinoculated with the WT clone (Fig. 1B, left panel). Deletions between positions -136 and -42 resulted in comparable accumulation of the new sgRNA, indicating that this region does not contain regulatory elements affecting sgRNA transcription and it is not needed to promote sgRNA synthesis.

In a second group of constructs, the $3^{\prime}$ boundary of the duplicated promoter was mapped using a constant $5^{\prime}$ terminus at position -42 and variable $3^{\prime}$ termini at positions $+206,+114$, $+50,+28$, and +6 downstream of the CP sgRNA transcription start site (Fig.1B, right panel). Again, these fragments were PCR amplified from CLBV-IC, cloned into $c l b v 3^{\prime}$, and, after inserting the $g f p$ gene at the PmlI site downstream of the duplicated promoter (Fig. 1A), the new vectors were agroinoculated in $N$. benthamiana. Northern blot analysis of RNAt from leaves at $16 \mathrm{dpi}$ showed that increasing deletions between positions +206 and +50 induced higher accumulation of the new sgRNA (Fig. 1B, right panel), confirming that this genomic region is an inhibitory sequence that modulates $\mathrm{CP}$ sgRNA transcription (Renovell et al. 2010). However, deletions until positions +28 and +6 decreased the amount of the new sgRNA, indicating that the $3^{\prime}$ border of a fully active CP sgRNA promoter is located between nucleotides +50 and +28 .

CLBV was detected by RT-PCR and Northern blot analysis in noninoculated upper leaves of $N$. benthamiana plants agroinoculated with all constructs described (data not shown), indicating that the resulting viruses retained their capacity to systemically infect $N$. benthamiana plants. The vector with a duplicated promoter in the $3^{\prime}$ UTR comprising the sequence between positions -42 and +50 around the CP sgRNA transcription start site was named $c l b v 3^{\prime} p r$ and the same vector expressing GFP was named $c l b v 3^{\prime} p r$-GFP.

The CLBV gRNA and the two natural sgRNAs accumulated in $N$. benthamiana leaves agroinoculated with the different vectors to a lower level than in those agroinoculated with the WT clone (Fig. 1B), suggesting that expression of the new sgRNA could compromise transcription of the gRNA and the MP and CP sgRNAs. Because transcription of the new sgRNA from the clbv3'pr-based vectors was much higher than that of the CP sgRNA and the $\mathrm{CP}$ is required for viral accumulation (Renovell et al. 2010), we reasoned that CP synthesis and, thus, viral accumulation might be increased by putting the $\mathrm{CP}$ gene under the control of the duplicated minimum promoter 
and the foreign sequences under the control of the natural $\mathrm{CP}$ sgRNA promoter. To test this hypothesis, a unique $P m l \mathrm{I}$ restriction site was added in the intergenic region between ORF 2 and ORF 3 , just upstream of the CP translation start codon, thus obtaining the $c l b v I N$ vector. Viral gRNA accumulated at a similar level in $N$. benthamiana leaves agroinoculated with $c l b v I N$ or with the WT construct as detected by real-time RTPCR (data not shown), indicating that this modification did

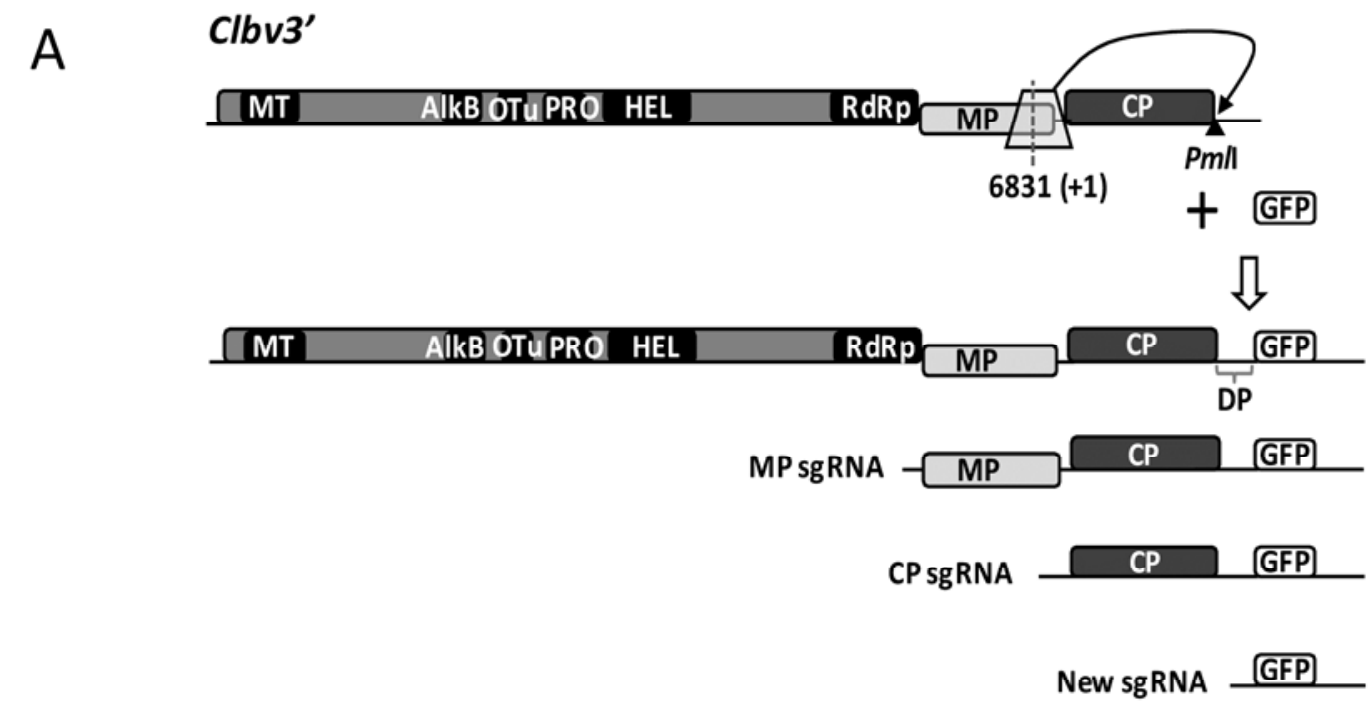

B
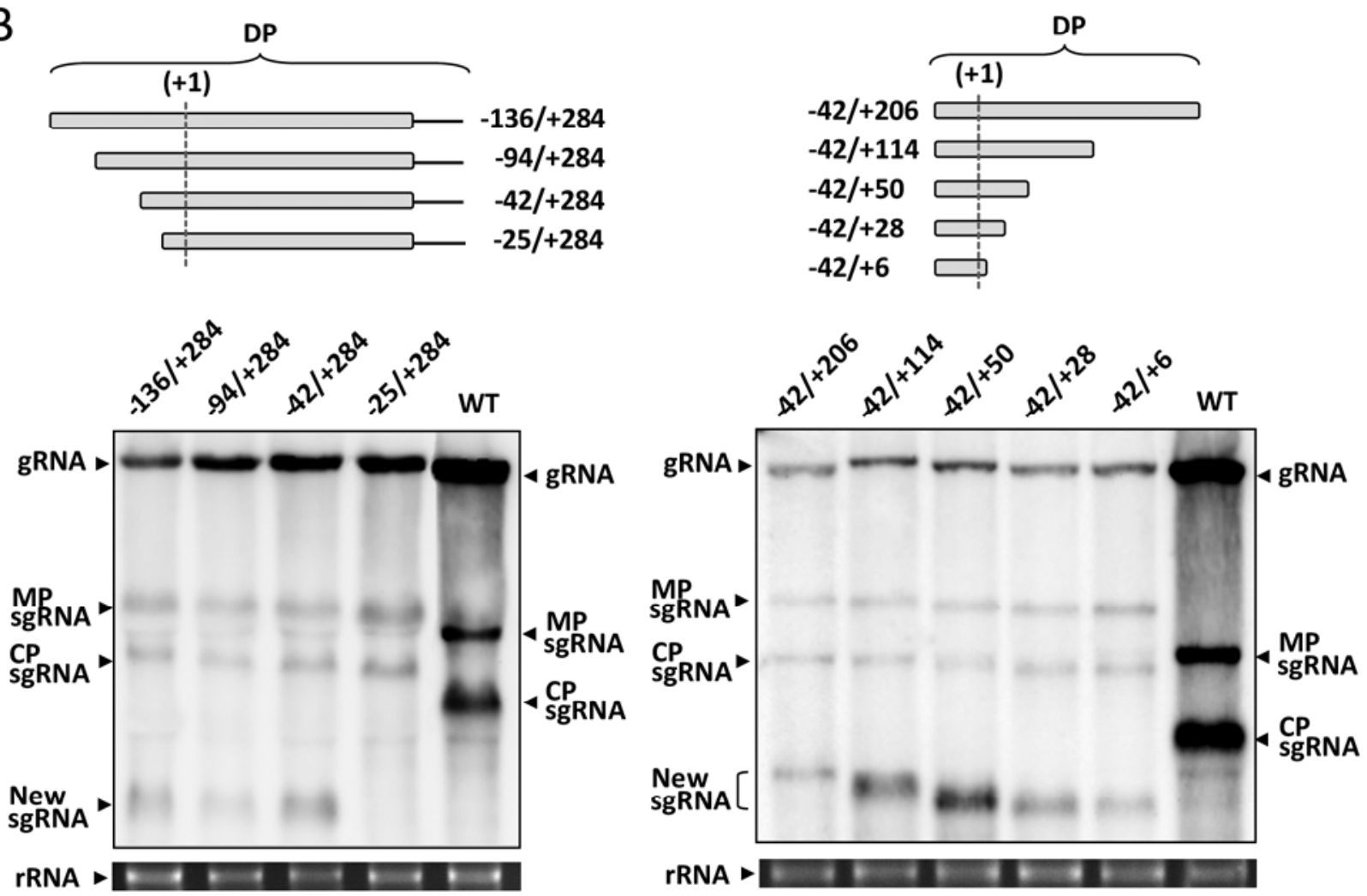

Fig. 1. Delineation of the boundaries of the coat protein subgenomic RNA (CP sgRNA) duplicate promoter used in Citrus leaf blotch virus (CLBV)-based vectors. A, Outline of the strategy followed to map the $5^{\prime}$ and $3^{\prime}$ borders of the duplicate promoter (DP) by inserting fragments of different size around the CP sgRNA transcription start site into the PmlI site of the $c l b v 3^{\prime}$ vector and the expected viral RNAs. Dotted line indicates the transcription start site of the CP sgRNA (+1) located at position 6,831 in the CLBV genome; shaded boxes represent the predicted open reading frames (ORF) and functional domains in the CLBV genome $(\mathrm{MT}=$ methyl-transferase, $\mathrm{AlkB}=$ AlkB-like peptidase, $\mathrm{OTu}=\mathrm{OTu}$-like peptidase, $\mathrm{PRO}=$ protease, $\mathrm{HEL}=$ helicase, $\mathrm{RdRp}=\mathrm{RNA}$-dependent RNA polymerase, and MP = movement protein); solid black lines represent untranslated regions (UTR); and the white box represents the green fluorescent protein $(g f p)$ gene or the 154-bp fragment thereof cloned downstream of the DP. B, Schematic diagram showing the $5^{\prime}$ and $3^{\prime}$ end of DP fragments used to map the 5' (left panel) or the 3' (right panel) borders, and Northern blot analyses of total RNA extracts (RNAt) from Nicotiana benthamiana leaves agroinoculated with the wild-type CLBV-IC clone (WT) or with different mutant constructs at 16 days postinoculation. The membrane was hybridized with a digoxigenin-riboprobe specific for the CLBV 3' UTR. Numbers indicate nucleotide positions relative to the CP sgRNA transcription start site (+1). Arrowheads and bracket indicate positions of the gRNA (genomic RNA) and sgRNAs in plants infected with the WT virus (right) or with the mutants (left). The increased size of the MP and CP sgRNAs of the mutant vectors causes reduced mobility in comparison with the cognate WT sgRNAs. Size differences among the new sgRNAs from different mutants can be observed in the right panel. GelRed staining of ribosomal RNA (rRNA) was used as loading control. 
not affect virus infectivity. The promoter fragment $-42 /+50$ around the transcription start site of the CP sgRNA, carrying a $P m l$ I restriction site in its $5^{\prime}$ end, was cloned in the PmlI site of $c l b v I N$ to obtain the $c l b v I N p r$ vector. The $g f p$ gene was then inserted in the new PmlI site upstream of the duplicated promoter to obtain the clbvINpr-GFP clone, in which $g f p$ was expressed under the control of the native CP sgRNA promoter and the $\mathrm{CP}$ gene under the duplicated minimum promoter (Fig. 2A). Agroinoculation of clbvINpr-GFP in N. benthamiana leaves resulted in efficient replication and movement of the viral progeny. Northern blot hybridization of RNAt from agroinoculated and systemically infected leaves revealed an extra 3' co-terminal sgRNA (GFP sgRNA) of the expected size between the MP and the CP sgRNAs, with the MP sgRNA showing slower electrophoretic mobility due to its size increase and the CP sgRNA faster mobility due to the smaller size of its $5^{\prime}$ UTR (Fig. 2B).

To compare viral replication and foreign gene expression with the two CLBV vector variants (location of the foreign gene at the $3^{\prime}$ UTR or between ORF 2 and ORF 3), N. benthamiana plants were agroinoculated with $c l b v 3^{\prime} p r$-GFP or clbvINpr-GFP clones and the level of gRNA and GFP sgRNA accumulation and fluorescence emission were analyzed at 25 dpi in systemically infected leaves. Although gRNA accumulation estimated by real-time RT-PCR analysis (Ruiz-Ruiz et al. 2009) was approximately 10 times higher in plants agroinoculated with clbvINpr-GFP than in plants agroinoculated with $c l b v 3^{\prime} p r$-GFP (data not shown), the amount of GFP sgRNA estimated in Northern blots using a Luminescent Image Analyzer LAS-3000 (FujiFilm, Tokyo) was approximately 10 times lower in the first than in the second plants (Fig. 2B). This comparison was repeated twice using five plants per assay. GFP expression in plants agroinoculated with $c l b v 3^{\prime} p r$ GFP was first observed at $11 \mathrm{dpi}$ as small fluorescent spots on inoculated leaves (Fig. 3A, left panel) that increased in size with time. At approximately $15 \mathrm{dpi}$, fluorescence was observed in systemically infected leaves, first in the veins and then in other tissues (Fig. 3A, right panel). The amount of GFP in these leaves was estimated as approximately $16 \mu \mathrm{g} \mathrm{g}^{-1}$ of fresh tissue by Western blot analysis. Contrastingly, fluorescence was not observed in plants agroinoculated with clbvINpr-GFP, although Western blot analysis showed GFP accumulation of approximately $3 \mu \mathrm{g} \mathrm{g}^{-1}$ of fresh tissue in systemically infected leaves of these plants (Fig. 3B).

\section{Genetic stability of CLBV-based vectors in $N$. benthamiana plants.}

Viral vectors are often unstable and tend to lose the inserted sequence by recombination with subsequent loss of its function. Therefore, elucidation of factors that favor those recombination events is critical to improve vector stability. We first examined the effect of the duplicated promoter size on the stability of the $c l b v 3$ ' $p$-derived vectors by agroinoculating five $N$. benthamiana plants with the constructs used to map its $5^{\prime}$ boundary and then examining the gRNA integrity of the virus progeny in inoculated and systemically infected leaves at 13 and 20 dpi, respectively, by RT-PCR analysis with primers encompassing the promoter insertion site in the CLBV genome. Although no recombination event was detected in agroinoculated leaves, in systemically infected leaves, larger duplicated promoters resulted in higher recombination rates. Thus, in three of the five plants agroinoculated with the construct carrying the largest duplicated promoter $(-136 /+284)$, the size of the RT-PCR-amplified product was smaller than expected whereas, in four out of five plants inoculated with the construct carrying the $-42 /+284$ promoter, a unique DNA band of the expected size was amplified (data not shown).
To assess the influence of the foreign sequence size on vector stability, five different DNA fragments from 1,645 to 154 nt were cloned into the $c l b v 3^{\prime} p r$ or the $c l b v I N p r$ vectors and the resulting constructs were agroinoculated in N. bentham-
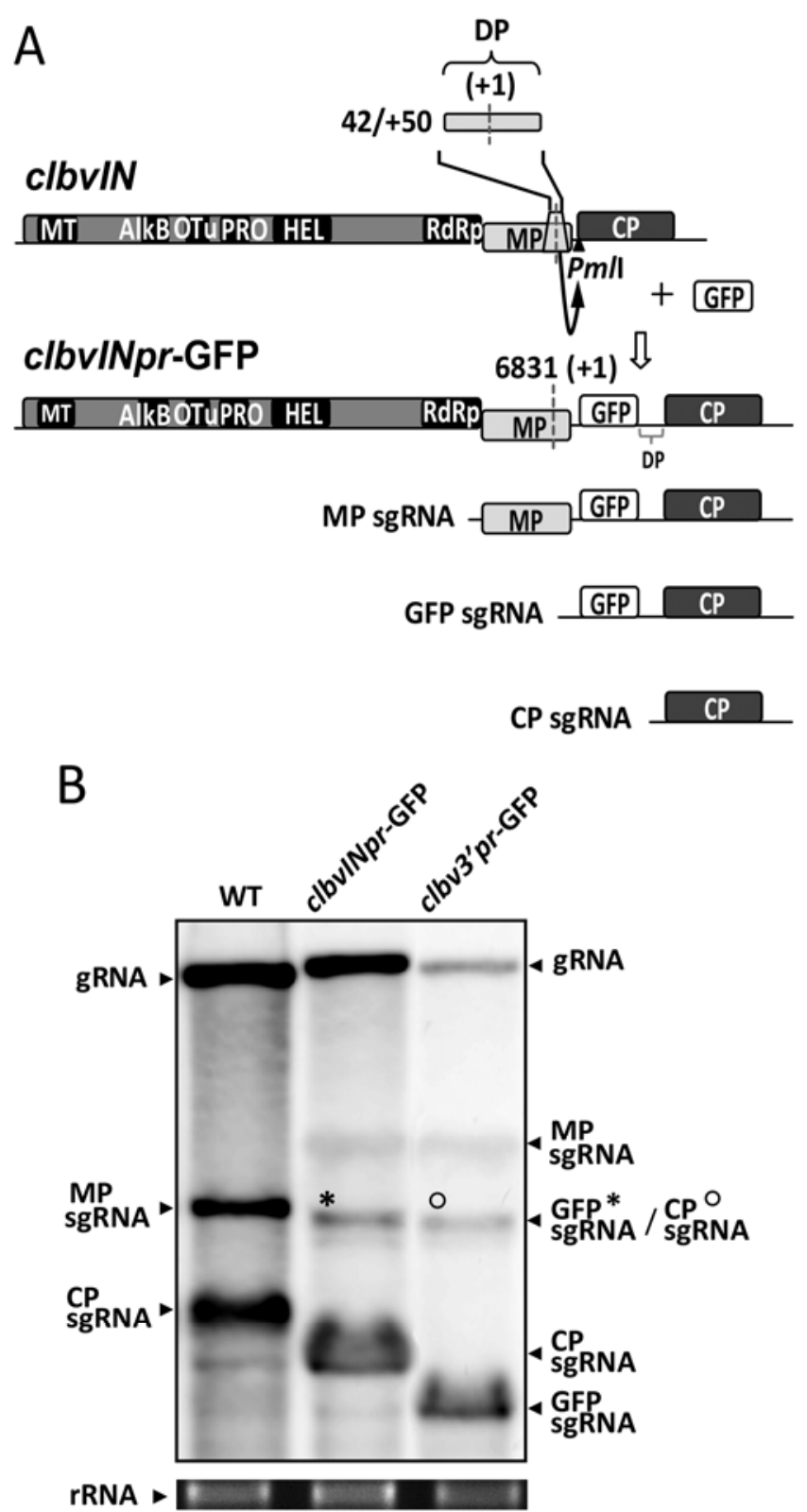

Fig. 2. Viral RNA accumulation in Nicotiana benthamiana plants agroinoculated with the wild-type Citrus leaf blotch virus (CLBV)-IC clone (WT) or with the clbvINpr or clbv3 pr vectors expressing the green fluorescent protein (GFP) (clbvINpr-GFP or clbv3 pr-GFP, respectively). A, Cloning strategy for duplication of the $-42 /+50$ fully active minimum promoter to obtain the clbvINpr-GFP vector and the expected RNAs derived. Dotted line indicates the transcription start site of the coat protein subgenomic RNA (CP sgRNA) (+1); shaded boxes represent the predicted open reading frames and functional domains $(\mathrm{MT}=$ methyl-transferase, $\mathrm{AlkB}=$ AlkB-like peptidase, $\mathrm{OTu}=\mathrm{OTu}$-like peptidase, $\mathrm{PRO}=$ protease, $\mathrm{HEL}=$ helicase, $\mathrm{RdRp}=\mathrm{RNA}$-dependent RNA polymerase, and MP $=$ movement protein); solid black lines represent untranslated regions (UTR); DP represents the duplicated promoter; and GFP represents the new $g f p$ gene inserted. B, Northern blot analysis of total RNA extracts from $N$. benthamiana leaves agroinoculated with the WT or with the clbvINpr-GFP or $c l b v 3^{\prime} p r$-GFP constructs at 16 days postinoculation. The membrane was hybridized with a digoxigenin-riboprobe specific for the CLBV 3' UTR. Arrowheads indicate positions of the genomic RNA (gRNA) and sgRNAs in plants infected with WT CLBV (left) or with the mutants (right). GelRed staining of rRNA was used as loading control. 
iana plants. These fragments corresponded to the RNA 2 of Citrus psorosis virus (CPsV) (1,645 nt), the complete gfp gene (720 nt), and different fragments thereof (414, 253, and 154 nt). Although all constructs cloned in clbv3 pr retained the insert in agroinoculated leaves at $13 \mathrm{dpi}$, in systemically infected leaves, the vector expressing the CPsV RNA 2 had lost the insert in the five agroinoculated plants at $20 \mathrm{dpi}$, the vector expressing the complete $g f p$ gene showed recombination events in 3 of 32 plants at $20 \mathrm{dpi}$ and in 18 plants at $40 \mathrm{dpi}$, and only constructs carrying fragments smaller than the $g f p$ gene retained the insert for at least $60 \mathrm{dpi}$. In some plants showing reorganization of the viral genome, RT-PCR analysis with primers flanking the promoter insertion site showed a DNA band of the
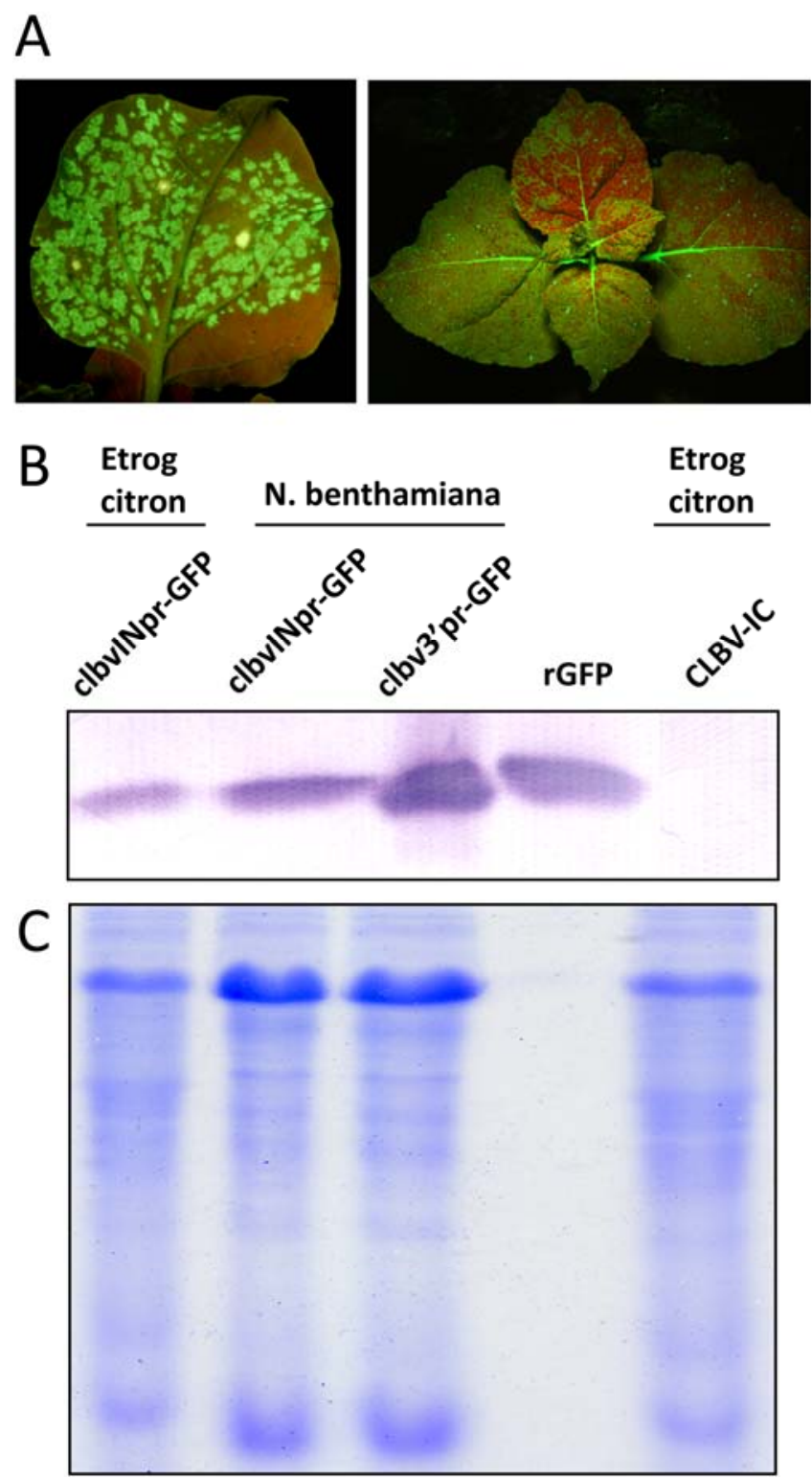

Fig. 3. Green fluorescent protein (GFP) detection in plants inoculated with Citrus leaf blotch virus (CLBV)-based vectors expressing GFP. A, Fluorescence observed in Nicotiana benthamiana plants agroinoculated with the $c l b v 3^{\prime} p r$-GFP clone: agroinoculated leaves at 16 days postinoculation (dpi) (left) and systemically infected leaves at 20 dpi (right). Photographs were taken under illumination with a handheld UV lamp. B, Western blot analysis of leaf proteins from $N$. benthamiana plants agroinflitrated with clbvINpr-GFP or clbv3'pr-GFP vectors and from Etrog citron inoculated with $c l b v I N p r$-GFP or CLBV-IC-derived virions, using a mixture of two anti-GFP monoclonal antibodies. A recombinant GFP protein (rGFP) was used as control. C, Equal protein loading was estimated by staining a parallel gel with Coomassie blue. size expected for the complete inserted sequence and others of smaller size (Fig. 4A, lane 2), suggesting a viral population with two or more different genomic sizes after appearance of recombinant sequences whereas, in other plants, a unique band corresponding to the reorganized virus genome was observed (Fig. 4A, lanes 3 and 4). Sometimes the most conspicuous PCRamplified DNA band co-migrated with that amplified from the WT clone, suggesting precise deletion of the insert by nonhomologous recombination. However, cloning and sequencing DNA products of this mobility, PCR-amplified from two different plants, revealed deletion of the inserted sequence plus an additional $8 \mathrm{nt}$ of the $3^{\prime}$ UTR. Similar analysis of the DNA band migrating between those of the WT and the complete insert (Fig. 4A, lane 3) showed the loss of a $g f p$ fragment between nucleotide positions 90 and 703 of this gene. Recombination events were also detected by Northern blot analysis (Fig. 4B).

When the same DNA fragments were inserted in $c l b v I N p r$, recombination events were detected only in systemically infected leaves of $N$. benthamiana plants agroinoculated with the vector carrying the CPsV RNA2 (data not shown).

Genetic stability of CLBV-based vectors in citrus plants.

To examine the stability of the clbvINpr vector in citrus plants, purified virions from $N$. benthamiana plants agroinoculated with the $c l b v I N p r$-GFP clone were slash inoculated on the trunk bark of two Etrog citron (Citrus medica L.) plants. Both plants became systemically infected, as detected by RT-PCR using RNAt from the first flush at $45 \mathrm{dpi}$. A unique band of the size expected for the construct carrying the full $g f p$ sequence was PCR amplified using primers flanking the promoter insertion site, suggesting stable replication of this viral vector not only in N. benthamiana but also in citrus plants. Although intensity of the GFP fluorescence in citrus was too weak to be directly observed, Western blot analysis of leaf extracts using a specific antibody showed that these plants accumulated approximately $0.6 \mu \mathrm{g}$ of GFP per gram of fresh tissue (Fig. 3B).

Genetic stability of the clbvINpr vector was also examined in other citrus species by graft inoculating C. excelsa Wester, Mexican lime [C. aurantifolia (Christm.) Swing.], Eureka lemon [C. limon (L.) Burm. f.], rough lemon (C. jambhiri Lush.), Dweet tangor [C. tangerina Hort. ex Tan. $\times C$. sinensis (L.) Osb.], and C. macrophylla Wester plants with bark pieces from infected Etrog citron. Vector stability in these plants and in Etrog citron was monitored for 21 months (at least six to seven consecutive flushes) by RT-PCR analysis with primers flanking the promoter insertion site. A unique band of the size expected for the construct carrying the full $g f p$ insert was obtained with all samples, demonstrating long-term stability of this vector in different citrus species and hybrids.

Mechanical inoculation of two Etrog citron plants with virions purified from $N$. benthamiana plants agroinoculated with the $c l b v 3^{\prime} p r$-GFP clone yielded successful infection in only one of the plants, which showed low virus titer and loss of the insert by recombination as revealed by RT-PCR analysis with primers flanking the promoter insertion site. However, in Mexican lime and Eureka lemon plants slash inoculated with virions from $N$. benthamiana carrying a 253-nt fragment of the $g f p$ gene (agroinoculation with the $c l b v 3^{\prime} p r$-253GFP vector), the insert has remained stable in the virion progeny for at least 10 months. These results confirm that, as observed in $N$. benthamiana plants, vectors carrying smaller inserts tend to be more stable.

\section{CLBV-based vectors expressing GFP trigger} RNA silencing of a $g f p$ transgene in citrus plants.

Transgenic Mexican lime and Eureka lemon plants constitutively expressing GFP were graft inoculated with bark pieces 
from an Etrog citron plant infected with virions derived from the clbvINpr-GFP vector and the onset of $g f p$ silencing was monitored by fluorescence observation under UV light. Although nontransgenic citrus plants appeared dark red due to chlorophyll autofluorescence, transgenic citrus expressing GFP appeared green (Fig. 5C, F, and J). Transgenic citrus plants inoculated with virions derived from the $c l b v I N p r$-GFP construct developed silenced foci in leaf primordia, young and old leaves, thorns, and stems (Fig. 5). A remarkable decrease of GFP fluorescence was observed in shoot tips of these plants (Fig. 5G) in comparison with equivalent shoot tips from plants inoculated with the WT virions (Fig. 5H), thus confirming that CLBV is able to invade meristematic regions. The silencing pattern was different in both transgenic citrus species. Although Mexican lime showed scattered nonfluorescent dark spots on the leaves (Fig. 5A and B), the silenced areas in Eureka lemon leaves appeared along the veins and then spread to a wider area (Fig. $5 \mathrm{D}$ and $\mathrm{E}$ ), suggesting different viral accumulation patterns in both citrus hosts. Occasionally, the silencing phenotype was uniform and affected large leaf areas. The GFP silencing phenotype has been observed in successive flushes for at least 21 months, being more intense in the second and following flushes than in the first. In silenced plants, CLBV could be detected by RT-PCR in most leaf regions regardless of the silencing phenotype and, in all cases, it contained the $g f p$ insert, suggesting that a threshold level of virus accumulation may be required to induce efficient VIGS in citrus plants, as observed with other plant viruses (Faivre-Rampant et al. 2004).

Slash inoculation of $g f p$-transgenic Mexican lime and Eureka lemon plants with virions derived from the $c l b v 3^{\prime} p r$-GFP vector induced the silencing phenotype only in the first flush of some plants, suggesting that the silencing phenotype developed only in plants where the CLBV vector retained the foreign insert. To confirm this hypothesis, transgenic Mexican lime and Eureka lemon plants were inoculated with virions derived from the clbv3'pr-253GFP vector. All these plants have shown a silencing phenotype identical to that observed in plants inoculated with $c l b v I N p r$-GFP-derived virions in successive flushes for at least 10 months.

We examined whether the silencing phenotype was associated with low transgene expression by comparing GFP mRNA accumulation in $g f p$-transgenic Eureka lemon and Mexican lime plants inoculated with WT CLBV or with virions derived from the $c l b v 3^{\prime} p r$-253GFP vector by quantitative real-time RTPCR. Leaves showing the silencing phenotype had less than $65 \%$ GFP mRNA in comparison with their counterparts from plants inoculated with WT CLBV (Fig. 5K).

\section{CLBV-based vectors can trigger silencing of endogenous citrus genes.}

The ability of CLBV-derived vectors to silence endogenous citrus genes was tested, using as targets the $p d s$ and a citrus homologue of the tobacco su gene, required for chlorophyll production (Fitmaurize et al. 1999), because lack of function of both genes incite a visible phenotype (Igarashi et al. 2009; Kumagai et al. 1995; Ratcliff et al. 2001; Ruiz et al. 1998). For this purpose, a 157-bp fragment of the $p d s$ gene from Valencia late sweet orange [C. sinensis (L.) Osb.] was cloned into the $c l b v 3^{\prime} \mathrm{pr}$ vector (clbv3'pr-157PDS) that was then agroinoculated in $N$. benthamiana plants, and the resulting recombinant virions were slash inoculated onto citrus plants. PDS is an enzyme required for biosynthesis of carotenoid pigments protecting chlorophyll from photo-oxidation, and $p d s$ silencing causes photobleaching. Although no silencing phenotype was observed in $N$. benthamiana plants agroinoculated with clbv3'pr-157PDS vector, probably due to low nucleotide identity between $N$. benthamiana and citrus pds genes (80\%), mechanical inoculation of four C. excelsa plants with virions purified from those $N$. benthamiana plants induced photobleaching in the leaves of the first flush. Photobleaching was first confined to leaf veins and later developed vein banding (Fig. 6A). The silencing phe-
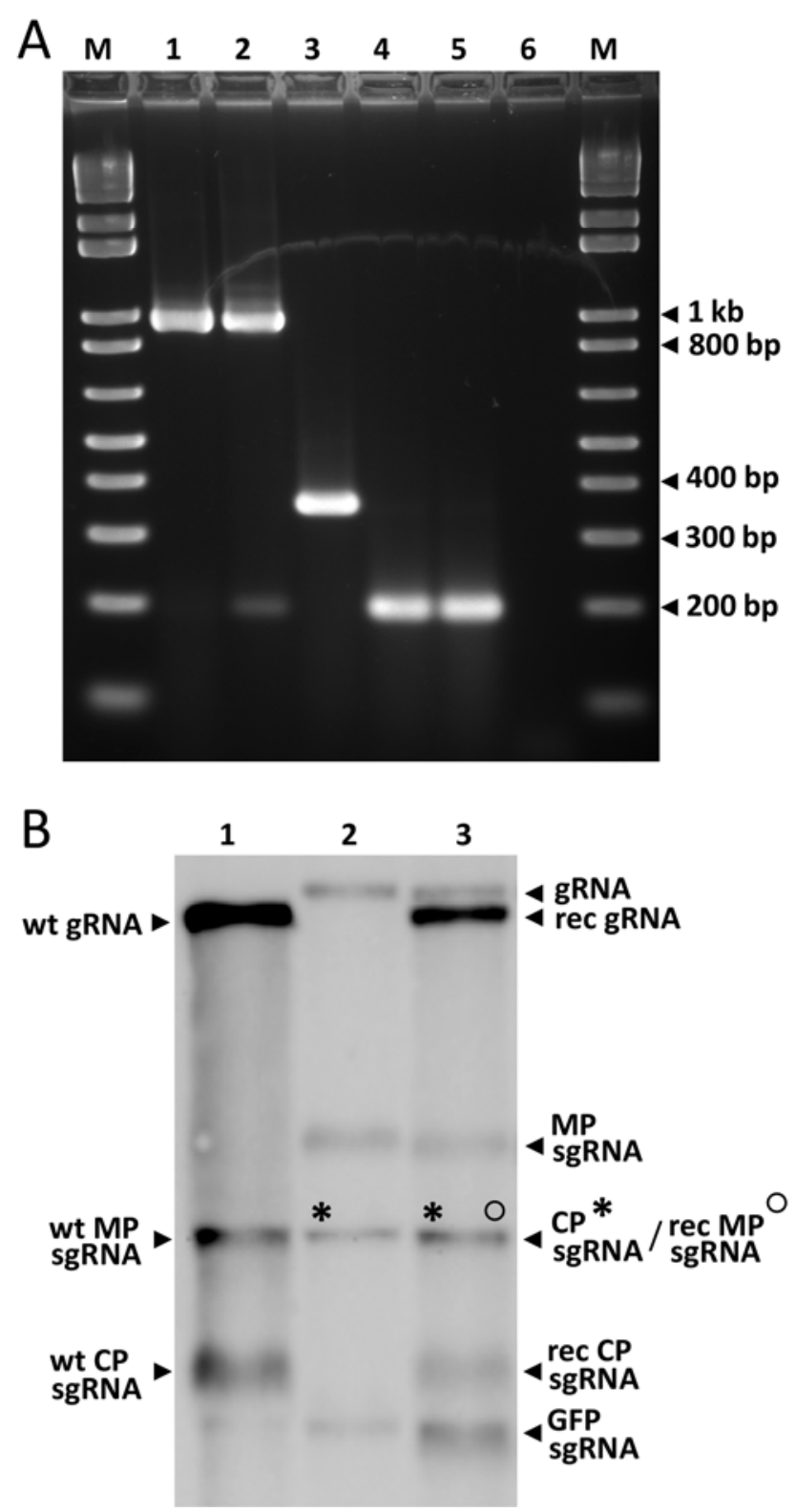

Fig. 4. Recombination analysis of Citrus leaf blotch virus (CLBV) mutants. A, Reverse-transcriptase polymerase chain reaction analysis of total RNA from Nicotiana benthamiana agroinoculated with the clbv3 pr vector expressing the green fluorescent protein (GFP) (clbv3 pr-GFP) using primers KU17L-KU7L flanking the promoter insertion site: lane 1, mutant keeping the whole $g f p$ insert; lane 2, mixed viral population, with some mutants carrying the whole insert and others that lost a $g f p$ fragment after recombination; lane 3 , a uniform recombinant population lacking the $g f p$ fragment between positions 90 and 703; lane 4, a uniform recombinant population lacking the whole $g f p$ fragment plus the first 8 nucleotides of the 3' untranslated region (UTR); lane 5, wild-type (WT) CLBV; lane 6, healthy plant; M, 1-Kb Plus molecular size ladder. B, Northern blot analysis of total RNA from systemically infected leaves of $N$. benthamiana plants agroinoculated with lane 1, the WT CLBV-IC clone; lane 2, clbv3'pr carrying the $-42 /+114$ duplicate promoter; or lane 3 , the cognate $c l b v 3^{\prime} p r$-GFP vector at 25 days postinoculation. The latter contains a mix of viral RNAs carrying the whole $g f p$ insert and others that lost it by recombination. The recombinant movement protein subgenomic RNA (rec MP sgRNA) and the nonrecombinant coat protein (CP sgRNA) show the same electrophoretic mobility. The membrane was hybridized with a digoxigeninriboprobe specific for the CLBV 3' UTR. 
notype was usually observed in fully expanded leaves and rarely in young developing leaves, with the discolored areas remaining in the old leaves. The photo-bleaching phenotype was detectable in leaves of successive flushes for at least 8 months.
Inoculation of $C$. excelsa plants with a $c l b v 3^{\prime} p r$ vector carrying a 241-nt fragment of the $s u$ gene from Valencia late sweet orange (clbv3'pr-241SU) showed a yellowing phenotype in leaves indicating chlorophyll deficiency (Fig. 6B). This silencing phenotype appeared in younger leaves and was more wide-
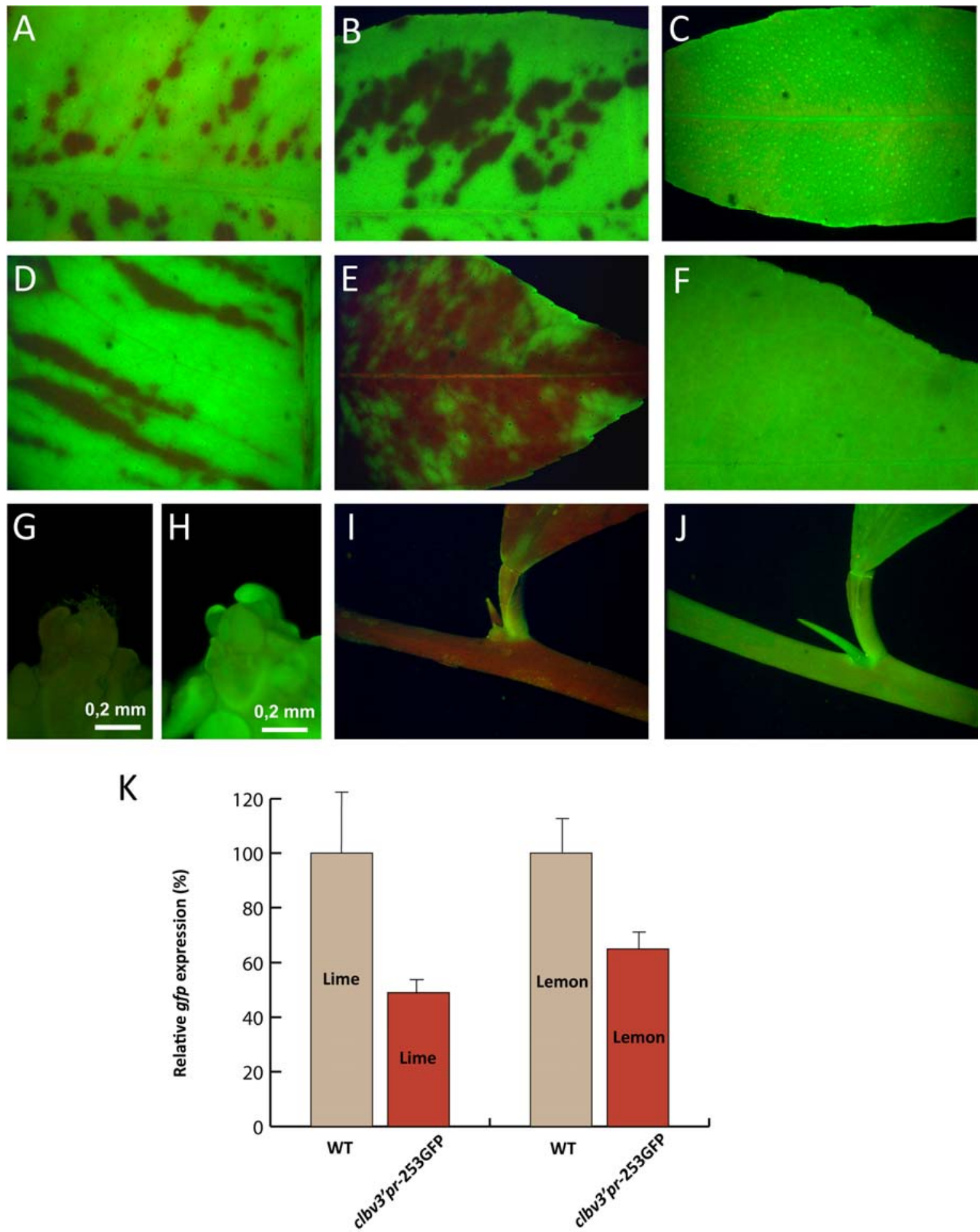

Fig. 5. Green fluorescent protein (GFP) silencing in transgenic citrus plants after inoculation with mutant Citrus leaf blotch virus (CLBV) virions containing an ectopic $g f p$ gene. Photographs show silencing phenotypes on Mexican lime A, young and $\mathbf{B}$, mature leaves and $\mathbf{G}$, shoot tip and Eureka lemon $\mathbf{D}$, young and $\mathbf{E}$, old leaf blades or I, stem, thorn, and young leaf petiole after inoculation with mutant virions derived from the clbvINpr-GFP clone. Similar tissues from $\mathbf{C}$ and $\mathbf{H}$, Mexican lime and $\mathbf{F}$ and $\mathbf{J}$, Eureka lemon plants inoculated with wild-type CLBV (WT) virions show GFP fluorescence. K, Relative accumulation of $g f p$ transcripts in $g f p$-transgenic Eureka lemon and Mexican lime plants slash inoculated with WT or with virions derived from the $c l b v 3^{\prime} p r$-253GFP vector. The amount of $g f p$ transcript was normalized to that of the actin gene in the same plants. The average expression in control plants infected with WT CLBV was considered 100, and the normalized expression in plants infected with the mutant virions was relative to the average of the control plants. Bars represent standard deviation values. 
spread than the pds-silencing phenotype. The yellowing phenotype remained in old leaves.

Quantification of $p d s$ and $s u$ mRNAs by real-time RT-PCR showed that citrus leaves with a silencing phenotype had lower mRNA accumulation than similar leaves from plants infected with WT CLBV (Fig. 6C). Silencing with the vector carrying the $p d s$ fragment was less efficient than with the vector carrying the $s u$ fragment.

\section{DISCUSSION}

We have developed CLBV-based vectors useful to express foreign genes and to trigger VIGS in citrus plants. A viral vector derived from Citrus tristeza virus (CTV) was used to express a foreign protein in citrus (Folimonov et al. 2007) but this is the first report of VIGS in these woody plants. In comparison with the CTV-based vector, the CLBV-based vectors developed here offer the following potential advantages: i) CLBV causes a symptomless infection in most citrus species and cultivars (Galipienso et al. 2000; Navarro et al. 1984; Vives et al. 2008a,b); therefore, phenotypic expression of gene silencing would not be masked; ii) in contrast with CTV, CLBV is not phloem limited; thus, the vectors described here would be appropriate for gene expression or silencing in nonphloem tissues, including meristematic regions; and iii) in contrast to CTV, CLBV is not transmitted by vectors and, therefore, it could be safely used in future field experiments.

In a previous work, we delimited the boundaries of the $\mathrm{CP}$ sgRNA promoter in its natural context between nucleotides -67 and +50 around the transcription start site (Renovell et al. 2010) but we did not test whether this reduced sequence was sufficient to promote the ectopic synthesis of a new sgRNA. Here, we addressed this issue and delimited the minimal functional promoter by duplicating variable sequence fragments around the CP sgRNA transcription start site at the 3' UTR of the CLBV gRNA. A 92-base fragment of the CP sgRNA promoter $(-42 /+50)$ duplicated in the CLBV genome led to the synthesis of a new sgRNA in infected plants, indicating that this fragment contains all the elements required for full promoter activity in vivo. Although deletions between positions -520 and -202 upstream of the transcription start site reduced the amount of CP sgRNA in its natural context (Renovell et al. 2010), in the duplicated promoter, deletions upstream of the nucleotide -42 did not affect accumulation of the new sgRNA, suggesting that reduction in the amount of CP sgRNA observed previously might be caused by reduced stability of viral RNAs due to the large deletion within the MP ORF that could affect the silencing suppressor activity of the MP (Renovell et al. 2012). Increasing deletions between positions +206 and +50 downstream of the CP sgRNA transcription start site induced higher accumulation of the new sgRNA, supporting previous suggestions that this region might be an inhibitory sequence to modulate CP sgRNA transcription (Renovell et al. 2010). However, further deletions between positions +50 and +6 resulted in reduced accumulation of the new sgRNA, indicating that this region must be necessary for efficient sgRNA transcription.

Remarkably, the new sgRNA synthesized after duplication of the minimum promoter at the $3^{\prime}$ UTR of the CLBV genome (clbv3'pr-GFP clone) accumulated to a higher level than the CP sgRNA synthesized under the control of the wild promoter in its natural context. This higher accumulation of the ectopic sgRNA might be due to i) an enhanced promoter activity derived from the lack of the inhibitory sequence downstream of position +50 present in the wild promoter or ii) the preference of virus replicase for an sgRNA promoter closer to the $3^{\prime}$ end of the gRNA, as reported for other plant viruses (Boccard and
Baulcombe 1993; French and Ahlquist 1988; Koev and Miller 2000; Wang and Simon 1997). However, because the ratio between the ectopic 3'-terminal sgRNA and the gRNA in plants agroinoculated with $c l b v 3^{\prime} p r$-GFP was higher than the ratio CP sgRNA/gRNA in plants infected with the WT CLBV, as determined with the Multi Gauge v3.0 software (FujiFilm) (data not shown), we believe that elimination of the inhibitory sequence is actually the most important reason for enhanced transcription of the ectopic 3'-terminal sgRNA.

Accumulation of gRNA was significantly lower in N. benthamiana plants agroinoculated with clbv3'pr-GFP than in plants infected with the WT. This reduction in viral accumulation might be due, in part, to the increased genome size. Indeed, viral accumulation was higher in plants infected with the WT CLBV than in those agroinoculated with a $c l b v 3^{\prime}$ construct carrying a duplicated $-25 /+284$ promoter fragment (not shown), even if this construct does not promote the synthesis of a new sgRNA. On the other hand, the synthesis of a new 3 '-terminal sgRNA compromises transcription of the two natural sgRNAs (MP and CP sgRNAs). Previous work with other viruses clearly showed a competition between different sgRNAs, with increased accumulation of one sgRNA resulting in a decrease of the others (Grdzelishvili et al. 2000; Johnson et al. 2003;
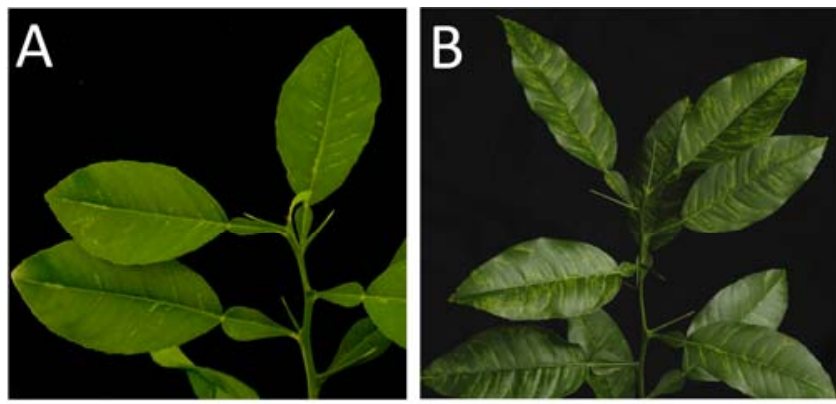

C

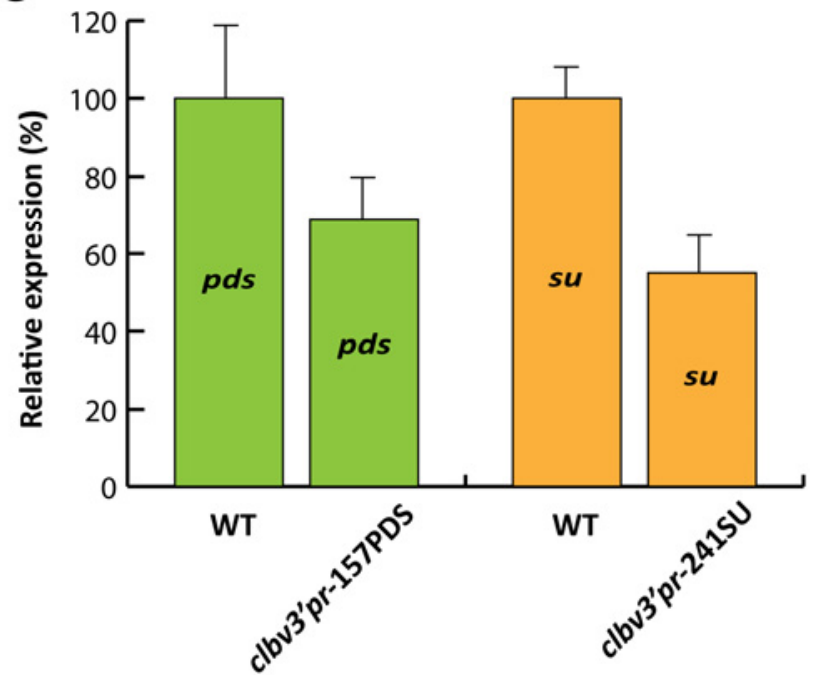

Fig. 6. Silencing phenotype of Citrus excelsa plants inoculated with mutant Citrus leaf blotch virus (CLBV) virions carrying A, a 157-bp fragment of the phytoene desaturase gene ( $p d s)$ or B, a 241-bp fragment of the homologue of the sulfur gene $(s u)$ from Valencia sweet orange. $\mathbf{C}$, Relative accumulation of the $p d s$ and $s u$ mRNAs in $C$. excelsa plants inoculated with wild-type CLBV (WT) or with virions derived from the $c l b v 3^{\prime} p r$ 157PDS and clbv3'pr-241SU vectors, respectively. For each gene, the amount of mRNA was normalized to that of the actin gene in the same plants. The average expression in control plants infected with WT CLBV was considered 100, and the normalized expression in plants infected with the mutant virions was relative to the average of the control plants. Bars represent standard deviation values. 
Shivprasad et al. 1999; Wang and Simon 1997). In N. benthamiana plants agroinoculated with the $c l b v 3^{\prime} p r$-GFP clone, expression of the new GFP sgRNA also reduced the amount of MP and CP sgRNAs and, thus, MP and CP synthesis. Because $\mathrm{CP}$ was shown to be necessary for viral accumulation in cells (Renovell et al. 2010), we decided to increase CP accumulation by putting the $\mathrm{CP}$ gene under the control of a duplicated $-42 /+50$ promoter and the $g f p$ gene under the control of the wild CP sgRNA promoter in the clbvINpr-GFP vector. The gRNA accumulation was higher in plants agroinoculated with this vector than in those agroinoculated with the $c l b v 3^{\prime} p r$ GFP vector, albeit slightly lower than in those infected with the WT CLBV, possibly due to higher transcription of the MP sgRNA in the latter. Reduced MP synthesis in the mutant vectors could hinder cell-to-cell and long-distance movement during virus infection. Moreover, because MP is the CLBV silencing suppressor (Renovell et al. 2012), reduced expression of this protein may further prevent viral accumulation in infected cells.

GFP fluorescence was observed in $N$. benthamiana leaves agroinoculated with the $c l b v 3^{\prime} p r$-GFP clone and in upper noninoculated leaves, demonstrating that this modified virus was able to move both cell to cell and long distance. Contrastingly, no fluorescence was observed in citrus plants infected with the same virions, likely due to higher instability or lower GFP accumulation in this host in comparison with $N$. benthamiana Because fluorescence is a convenient reporter, GFP expression in $N$. benthamiana plants agroinoculated with CLBV mutants derived from the $c l b v 3$ pr-GFP vector could be a helpful tool to analyze sequence motifs involved in CLBV replication, assembly, and movement in this host.

Instability associated with high error rates during RNA replication and frequent recombination events have been limiting factors in the use of plant viral vectors. Genetic variation of CLBV isolates from different geographical origins and citrus hosts was shown to be very low in comparison with most plant viruses (Vives et al. 2002c), indicating that CLBV is a very stable virus. Virions derived from the clbvINpr-GFP construct were more stable than those derived from clbv3'pr-GFP in both $N$. benthamiana and citrus plants. In citrus plants, virions derived from the first construct have remained stable for at least 21 months (six to seven consecutive flushes), whereas those derived from the second lost their $g f p$ insert after the first flush. However, when a $g f p$ fragment of $253 \mathrm{nt}$ was cloned in the $c l b v 3^{\prime} p r$ vector, no recombination events were detected in citrus plants after 10 months (three to four flushes). Similar results were obtained with Potato virus $X$-based vectors, where insertion of smaller fragments tended to be more stable (Avesani et al. 2007). Our results suggest that $c l b v 3^{\prime} p r$-derived vectors should not be used for protein expression in citrus but they could be used for gene silencing. Indeed, expression of gene fragments with this vector in citrus induced silencing of endogenous genes or a transgene.

A major challenge in post-genomic biology is assigning function to gene sequences identified by differential expression or large-scale genome sequencing. Presently, there are more than 230,000 EST available, derived from different cDNA libraries representing a wide range of citrus organs, developmental stages, genotypes, and plants subjected to diverse biotic and abiotic stresses (Forment et al. 2005). Furthermore, the genome sequences of two citrus species (C. clementina and $C$. sinensis) are also available. In plants, reverse genetics by functional gene knockout has been based on genetic transformation (Vance and Vaucheret 2001). However, this technique is time consuming and often requires generation and screening of many transgenic lines to obtain a few silenced individuals. As an alternative, reverse genetic approaches based on VIGS have been developed and successfully applied in several plant species (Becker and Lange 2010; Burch-Smith et al. 2004; Purkayastha and Dasgupta 2009; Robertson 2004). Our results showed that CLBV-based vectors induce reliable silencing of endogenous genes or a transgene in citrus plants. Further experiments aimed at silencing other endogenous citrus genes using the vectors developed here are in progress, with promising preliminary results.

Plant tissues that can be targeted by VIGS depend mostly on viral vector characteristics. CLBV accumulates in all tissues of citrus plants (Ruiz-Ruiz et al. 2009), including meristematic regions, as deduced from seed transmission (Guerri et al. 2004) and the difficulty to recover CLBV-free plants by shoottip grafting in vitro (Navarro et al. 1984). CLBV-based vectors carrying $g f p$ sequences were able to silence a $g f p$ transgene expressed in leaf primordia, young and old leaves, stems, thorns, and shoot tips of transgenic citrus plants. The ability of these vectors to induce VIGS in meristematic regions would enable studying genes involved in organ development pathways. Because these vectors were stable and induced the silencing phenotype in successive flushes for several months, they could possibly also be used to knock down genes involved in reproductive stages of the long-lived citrus plants.

In summary, it is expected that the CLBV-based vectors developed in this work will enable cost-effective screening of many citrus genes for which a function has yet to be discovered or confirmed, as well as expression of foreign proteins in these woody hosts. Once a viral vector has systemically infected a citrus plant, it can be easily graft inoculated to plants of other citrus varieties at either the juvenile or mature stage.

\section{MATERIALS AND METHODS}

\section{Plasmid constructs.}

The infectious CLBV construct pBIN35SRbz-CLBV (CLBV-IC) described previously (Vives et al. 2008a) (here named WT) contains a full-length cDNA of the CLBV gRNA cloned into the pBIN19 binary plasmid, between the duplicated $35 \mathrm{~S}$ promoter of Cauliflower mosaic virus and the nopaline synthase terminator. This plasmid was mutated in order to generate CLBV-based vectors using standard techniques (Sambrook et al. 1989) and appropriate primers (Supplementary Table S1). All mutations performed on this plasmid were confirmed by sequencing and restriction analysis.

To introduce a unique PmlI restriction site in CLBV-IC, the 2,686-nt fragment located between restriction sites AgeI and ApaI of this clone, including the $3^{\prime}$ half of CP gene, the $3^{\prime}$ UTR, and a fragment of the pBIN19 plasmid, was PCR amplified with the primer pair KUV3/KUV6, and cloned into the pGEM-T plasmid (Promega Corp., Madison, WI, U.S.A.) to obtain pGEM-3 T. To add a PmlI site (CAC GTG) after the stop codon of the CP ORF, this plasmid was PCR amplified with the primer pair VV1/VV2, each containing half of the $P m l$ I restriction sequence at their $5^{\prime}$ end, and self-ligated to obtain the pGEM-3'Tpml plasmid. This clone was digested with AgeI and ApaI and the released fragment was cloned into the CLBV-IC plasmid digested with the same enzymes to obtain the $c l b v 3^{\prime}$ vector. To introduce a $P m l l$ site just before the start codon of the CP ORF, we followed the same strategy but using the plasmid pCP (Renovell et al. 2010), which included the $3^{\prime}$ half of MP and the $5^{\prime}$ end of the $\mathrm{CP}$ genes cloned into the pUC19 plasmid. This plasmid was amplified by PCR using primers MP2L and MP8D, each containing half of the PmlI restriction sequence at their $5^{\prime}$ end, and the PCR product was self-ligated to obtain the $p C P p m l$ plasmid. This clone was digested with $X h o \mathrm{I}$ and Bsu36I and the released fragment was cloned into the CLBV-IC plasmid digested with the same enzymes to obtain the $c l b v I N$ vector. 
The minimum sequence promoting transcription of an additional sgRNA was defined by testing sequence fragments of variable size around the $\mathrm{CP}$ sgRNA transcription start site, inserted at the PmlI site of the $c l b v 3^{\prime}$ vector (Fig. 1). To map the $5^{\prime}$ border of this minimum promoter, fragments with a constant $3^{\prime}$ terminus at nucleotide +284 downstream of the transcription start site (position +1 ) and variable $5^{\prime}$ termini located at the upstream positions $-136,-94,-42$, and -25 were PCR amplified using forward primers MP1U (-136), MP3U (-94), MP4U $(-42)$, and MP25U (-25) and the reverse primer MP2L (+284) containing GTG at its $5^{\prime}$ end to keep a $P m l$ I restriction site downstream of the duplicated promoter (Fig. 1B). After cloning these PCR products into the Pmll site of $c l b v 3$ ', a 154-nt fragment of the $g f p$ gene, C3 version (Crameri et al. 1996), was PCR amplified from the pCAM9R-GFP plasmid (provided by W. O. Dawson, University of Florida, Citrus Research and Education Center, Lake Alfred) with the primer pair G303D/ G456R and cloned into the new Pmll restriction site (Fig. 1A).

To map the $3^{\prime}$ border of the minimum promoter, the fragments $-42 /+206,-42 /+114$, and $-42 /+50$, with a constant $5^{\prime}$ terminus $(-42)$ and variable $3^{\prime}$ termini downstream of the CP sgRNA transcription start site, were PCR amplified from the CLBV-IC clone using the forward primer MP4U and the reverse primers MP6R (+206), MP7R (+114), and MP4R-P $(+50)$ containing GTG at their $5^{\prime}$ end to keep a $P m l$ restriction site downstream of the duplicated promoter as before (Fig. 1B). The fragments $-42 /+28$ and $-42 /+6$ were generated by hybridizing complementary oligonucleotides Pm28D and Pm28R, and Pm6D and Pm6R, respectively (Fig. 1B). Each of these fragments was cloned into the Pmll site of $c l b v 3^{\prime}$ and then the $g f p$ gene was PCR amplified from the pCAM9R-GFP plasmid with primers GFPF and GFPL and cloned into the new Pmll site of each construct (Fig. 1A). The construct with the duplicated promoter fragment $-42 /+50$ was named $c l b v 3$ pr and the cognate construct expressing GFP was named $c l b v 3$ prGFP.

The minimum promoter fragment $-42 /+50$ was also inserted between the MP and CP ORF using the $c l b v I N$ construct. For this purpose, the $-42 /+50$ fragment was PCR amplified from the CLBV-IC clone using the forward primer MP11D, containing GTG at its $5^{\prime}$ end, and the reverse primer MP4R, and the product was cloned into the Pmll-digested $p C P p m l$ plasmid to obtain the plasmid $p C P p r$. This plasmid was digested with $X h o I$ and Bsu36I and the released fragment was cloned into the CLBV-IC clone digested with the same enzymes to obtain the vector clbvINpr. Then, the $g f p$ gene, PCR amplified as before, was cloned into the Pmll-digested clbvINpr vector to obtain clbvINpr-GFP.

Fragments G154, G253, and G414 of the $g f p$ gene were PCR amplified from the pCAM9R-GFP plasmid, and a cDNA of the CPsV RNA2 (1,645 nt) was RT-PCR amplified using RNAt from a CPsV-infected citrus plant and appropriate primers. These amplicons were cloned into the Pmll-digested $c l b v 3^{\prime} p r$ and $c l b v I N p r$ vectors. Fragments of 157 and $241 \mathrm{nt}$ of the $p d s$ and $s u$ genes, respectively, were RT-PCR amplified from Valencia sweet orange RNAt and cloned into $c l b v 3^{\prime} p r$.

\section{Plant growth, agroinoculation of $N$. benthamiana leaves, and slash and graft inoculation of citrus plants.}

$N$. benthamiana plants were grown in small pots with an artificial potting mix (50\% vermiculite and $50 \%$ peat moss) in a plant growth chamber at 20 and $24^{\circ} \mathrm{C}$ (night and day, respectively), $60 \%$ humidity, and a regime of $16 \mathrm{~h}$ of light and $8 \mathrm{~h}$ of darkness. Citrus plants were grown in a glasshouse at 18 and $26^{\circ} \mathrm{C}$ (night and day, respectively), using 2-liter plastic containers filled with $50 \%$ sand and $50 \%$ peat moss and a standard fertilizing procedure (Arregui et al. 1982). C. excelsa Wester,
Mexican lime [C. aurantifolia (Christm.) Swing.], Eureka lemon [C. limon (L.) Burm. f.], rough lemon (C. jambhiri Lush.), Dweet tangor $[C$. tangerina Hort. ex Tan. $\times C$. sinensis $(\mathrm{L})$. Osb.], and C. macrophylla Wester were grown as seedlings and Etrog citron $(C$. medica $\mathrm{L}$.) was propagated on a rough lemon rootstock.

Recombinant CLBV clones were transfected to Agrobacterium tumefaciens cells, strain COR 308, carrying the helper plasmid pCH32 (provided by C. M. Hamilton, Cornell Research Foundation, Ithaca, NY, U.S.A.) as previously described (Vives et al. 2008a). In all agroinoculation experiments, $N$. benthamiana leaves were co-infiltrated with equal volumes of $A$. tumefaciens cultures carrying the CLBV-derived binary plasmids or the 19 gen of Tomato bushy stunt virus (pBI-19, provided by J. A. García, Centro Nacional de Biotecnología, CSIC, Madrid) that encodes a strong RNA silencing suppressor protein (Voinnet et al. 1999).

Semipurified virion extracts from agroinoculated $N$. benthamiana plants (Galipienso et al. 2000) were inoculated to citrus plants by stem slashing (Garnsey et al. 1977) with scalpel blades dipped in the viral extracts (Galipienso et al. 2000; Vives et al. 2008b). Bark pieces from citrus plants infected with the recombinant or the WT CLBV were used to graft inoculate other citrus species.

\section{RNA extraction, RT-PCR detection, and RNA quantification by real-time RT-PCR and Northern blot analysis.}

RNAt from inoculated plants was prepared from $500 \mathrm{mg}$ of leaf tissue using i) TRIzol reagent (Invitrogen, Carlsbad, CA, U.S.A.) following the manufacturer's instructions or ii) a standard protocol with two phenol/chloroform/isoamyl alcohol extractions, followed by RNA precipitation with $12 \mathrm{M}$ lithium chloride, and resuspension in $25 \mu \mathrm{l}$ of diethyl pyrocarbonatetreated distilled water (Ancillo et al. 2007). RNA content was measured in a NanoDrop spectrophotometer (Thermo Fisher Scientific, Wilmington, DE, U.S.A.) and adjusted to the same concentration for Northern blot and real-time RT-PCR analysis.

The sequences inserted in CLBV viral vectors were detected by conventional RT-PCR (Vives et al. 2002b) with the primer pairs KU17L/KU7L and MpC/MP3U flanking the two insertion sites. The DNA synthesized was visualized by $2 \%$ agarose gel electrophoresis and GelRed-staining (Biotium Inc., Hayward, CA, U.S.A.).

Accumulation of viral gRNA in plants inoculated with CLBV-derived constructs was determined by quantitative realtime RT-PCR performed in a Light-Cycler platform (Roche Diagnostics $\mathrm{GmbH}$, Mannheim, Germany) with $20-\mu$ l glass capillaries. Reverse transcription and amplification were performed using DNA-free (Turbo DNA-free kit; Ambion, Inc., U.S.A.) RNAt $(2 \mu \mathrm{l})$ adjusted to $10 \mathrm{ng} / \mu \mathrm{l}$ and primers and a TaqMan probe targeted to ORF 1 of the gRNA (Ruiz-Ruiz et al. 2009). Each sample was analyzed in duplicate in two independent assays.

In gene-silencing experiments, the mRNA level of endogenous citrus genes or transgenes was estimated by quantitative real-time RT-PCR using SYBR Green detection. DNA-free RNAt from plants infected with the WT or mutant CLBV was reverse transcribed using sGFPL primer for $g f p$ trangene and oligo (dT) for $p d s$, su, and actin genes and SuperScript II reverse transcriptase (Invitrogen). PCR amplification was performed with primers QsGFPF, QsGFPR, QPdsF, QPdsR, QsuF, and QsuR, designed with Primer Express Software (Applied Biosystems, Foster City, CA, U.S.A.) to exclude the gene regions cloned into the CLBV vector and, thus, ensure that only endogenous mRNA was amplified. Each sample was analyzed in triplicate using pooled leaf extracts from five independent 
plants. The mRNA amount estimated for each gene was normalized to the expression level of the citrus homologue of the actin11 gene in the same sample with primers CiACT11qF and CiACT11qR. The expression of each gene in plants infected with mutant CLBV virions relative to the control plants infected with WT CLBV was determined by the $2^{-\Delta \Delta C T}$ method (Livak and Schmittgen 2001).

Northern blot analysis of CLBV RNAs was performed according to Vives and associates (2002a) and Galipienso and associates (2004), with minor modifications. RNAt (3 to $5 \mu \mathrm{g}$ ) was denatured at $94^{\circ} \mathrm{C}$ for $5 \mathrm{~min}$ in $50 \%$ formamide, chilled on ice, separated by electrophoresis in formamide-formaldehydedenaturing $1.2 \%$ agarose gels in MOPS buffer, and electroblotted onto positively charged nylon membranes (Roche Diagnostics) at $250 \mathrm{~mA}$ for $1 \mathrm{~h}$ and $1 \mathrm{~A}$ for $15 \mathrm{~h}$, using $25 \mathrm{mM}$ phosphate buffer, $\mathrm{pH} 6.45$. Membranes were hybridized at $68^{\circ} \mathrm{C}$ with a DIG-labeled RNA probe specific for the CLBV 3' UTR, as in Galipienso and associates (2004) but including two extra washings with $0.1 \times \mathrm{SSC}(1 \times \mathrm{SSC}$ is $0.15 \mathrm{M} \mathrm{NaCl}$ plus 0.015 $\mathrm{M}$ sodium citrate) and $0.1 \%$ sodium dodecyl sulfate (SDS) at $68^{\circ} \mathrm{C}$ before incubation with the anti-DIG antibody. The reaction was developed using CPD-Star chemiluminescent substrate (Roche Diagnostics) and visualized with the Luminescent Image Analyzer LAS-3000 (FujiFilm) or with X-Ray films (Carestream Health Inc., Rochester, NY, U.S.A.). Quantification of the CLBV sgRNA in Northern blot images taken before saturation was performed with the Multi Gauge v3.0 software (FujiFilm).

\section{GFP detection.}

GFP accumulation was monitored by fluorescence observation and by Western blot analysis. In $N$. benthamiana plants agroinoculated with GFP-expressing vectors, fluorescence was observed under a long-wavelength UV lamp (Black Ray model B100AP; UV Products, Upland, CA, U.S.A.) and images were taken with a CANON EOS 300D digital camera using a yellow filter (Jos. Schneider Optische Werke, B+W Filter, Bad Kreuznach, Germany). GFP silencing in transgenic citrus plants was observed with a Leica MZ16 stereomicroscope (Leica Microsystems, Heerbrugg, Switzerland) using a high-energy light source and a GFP filter. Images were taken with a Leica DFC490 digital camera using the IM50 software (Leica Microsystems).

For Western blot analysis, $1 \mathrm{~g}$ of leaf tissue was ground in $4 \mathrm{ml}$ of protein extraction buffer (100 mM Tris-Cl [pH 6.8], $0.3 \%$ mercaptoethanol, and $0.2 \%$ polyvinylpyrrolidone) and successively centrifuged for $15 \mathrm{~min}$ at $2,500 \times g$ and $15 \mathrm{~min}$ at $10,000 \times g$. Supernatant $(20 \mu \mathrm{l})$ was boiled with loading buffer (Laemmli 1970) and electrophoresed in SDS polyacrylamide gels (14\% acrylamide) at $50 \mathrm{~V}$ for $1 \mathrm{~h}$ and then at $100 \mathrm{~V}$ until the bromophenol blue marker reached the lower gel edge. Proteins were electroblotted onto polyvinylidene difluoride membranes (Millipore, Billerica, MA, U.S.A.) using the appropriate buffer (Laemmli 1970). Serial dilutions (100 to $3,125 \mathrm{ng}$ ) of recombinant GFP (Roche Diagnostics) were included as standard to estimate GFP concentration in plant extracts. Equal protein loading was confirmed by staining a parallel gel with Coomassie blue. The membranes were incubated with a 1:2,000 dilution of a mixture of two anti-GFP monoclonal antibodies (Roche Diagnostics), and then with a 1:4,000 dilution of an anti-mouse antibody conjugated with alkaline phosphatase (Sigma-Aldrich, St. Louis) in TBS-T buffer $(20 \mathrm{mM}$ Tris- $\mathrm{Cl}$ [pH 7.5], $500 \mathrm{mM} \mathrm{NaCl}$, and $0.1 \%$ Tween-20). The reaction was developed with the CPD-Star chemiluminescent substrate (Roche Diagnostics) or with the chromogenic substrate 5-bromo-4-chloro-3-indolyl phosphate/ nitro blue tetrazolium.

\section{ACKNOWLEDGMENTS}

This work was supported by grants AGL2006-0316 and AGL200908226, co-financed by FEDER (European Fund for Regional Development) and by Ministerio de Ciencia e Innovación (MICINN), respectively. J. Agüero was recipient of a doctoral fellowship from the MICINN. S. Ruiz-Ruiz and M. del Carmen Vives were recipients of a contract from IVIA. We thank M. Cruz Castillo for assistance with relative quantification, M. Boil for excellent lab assistance, and J. Juárez for technical support to prepare photographs.

\section{LITERATURE CITED}

Adams, M. J., Candresse, T., Hammond, J., Kreuze, J. F., Martelli, G. P., Namba, S., Pearson, M. N., Ryu, K. H., Saldarelli, P., and Yoshikawa, N. 2012. Family Betaflexiviridae. Pages 920-941 in: Virus Taxonomy: IXth Report of the International Committee on Taxonomy of Viruses. A. M. Q. King, M. J. Adams, E. B. Carstens, and E. J. Lefkowitz, eds. Elsevier Academic Press, London.

Agustí, J., Merelo, P., Cercós, M., Tadeo, F. R., and Talón, M. 2008. Ethylene-induced differential gene expression during abscission of citrus leaves. J. Exp. Bot. 59:2717-2733.

Alós, E., Roca, M., Iglesias, D. J., Mínguez-Mosquera, M. I., Damasceno, C. M. B., Thannhauser, T. W., Rose, J. K. C., Talón, M., and Cercós, M. 2008. An evaluation of the basis and consequences of a stay-green mutation in the navel negra citrus mutant using transcriptomic and proteomic profiling and metabolite analysis. Plant Physiol. 147:1300-1315.

Ancillo, G., Gadea, J., Forment, J., Guerri, J., and Navarro, L. 2007. Class prediction of closely related plant varieties using gene expression profiling. J. Exp. Bot. 58:1927-1933.

Aprile, A., Federici, C., Close, T., De Bellis, L., Cattivelli, L., and Roose, M. 2011. Expression of the H+-ATPase AHA10 proton pump is associated with citric acid accumulation in lemon juice sac cells. Funct. Integr. Genomics 11:551-563.

Arregui, J. M., Ballester, J. F., Pina, J. A., and Navarro, L. 1982. Influencia del sustrato y de la fertilización en el crecimiento de plantas de lima Mejicana (Citrus aurantifolia (Chritm.) Swing). Anales Instituto Nacional de Investigaciones Agrarias (INIA) Serie Agricoloa 19:61-82.

Avesani, L., Marconi, G., Morandini, F., Albertini, E., Bruschetta, M., Bortesi, L., Pezzotti, M., and Porceddu, A. 2007. Stability of Potato virus $X$ expression vectors is related to insert size: Implications for replication models and risk assessment. Transgenic Res. 16:587-597.

Becker, A., and Lange, M. 2010. VIGS-genomics goes functional. Trends Plant Sci. 15:1-4.

Boava, L., Cristofani-Yaly, M., Mafra, V., Kubo, K., Kishi, L., Takita, M. Ribeiro-Alves, M., and Machado, M. 2011. Global gene expression of Poncirus trifoliata, Citrus sunki and their hybrids under infection of Phytophthora parasitica. BMC Genomics 12:39.

Boccard, F., and Baulcombe, D. 1993. Mutational analysis of cis-acting sequences and gene function in RNA3 of Cucumber mosaic virus. Virology 193:563-578.

Burch-Smith, T. M., Anderson, J. C., Martin, G. B., and Dinesh-Kumar, S. P. 2004. Applications and advantages of virus-induced gene silencing for gene function studies in plants. Plant J. 39:734-746.

Cercós, M., Soler, G., Iglesias, D., Gadea, J., Forment, J., and Talón, M. 2006. Global analysis of gene expression during development and ripening of citrus fruit flesh. A proposed mechanism for citric acid utilization. Plant Mol. Biol. 62:513-527.

Cervera, M., Navarro, A., Navarro, L., and Peña, L. 2008. Production of transgenic adult plants from clementine mandarin by enhancing cell competence for transformation and regeneration. Tree Physiol. 28:5566.

Crameri, A., Whitehorn, E. A., Tate, E., and Stemmer, W. P. C. 1996. Improved green fluorescent protein by molecular evolution using DNA shuffling. Nat. Biotechnol. 14:315-319.

Faivre-Rampant, O., Gilroy, E. M., Hrubikova, K., Hein, I., Millam, S., Loake, G. J., Birch, P., Taylor, M., and Lacomme, C. 2004. Potato virus $X$-induced gene silencing in leaves and tubers of potato. Plant Physiol. 134:1308-1316.

Fitzmaurice, W. P., Nguyen, L. V., Wernsman, E. A., Thompson, W. F., and Conkling, M. A. 1999. Transposon tagging of the sulfur gene of tobacco using engineered maize Ac/Ds elements. Genetics 153:1919-1928.

Folimonov, A. S., Folimonova, S. Y., Bar-Joseph, M., and Dawson, W. O. 2007. A stable RNA virus-based vector for citrus trees. Virology 368:205-216.

Forment, J., Gadea, J., Huerta, L., Abizanda, L., Agustí, J., Alamar, S., Alós, E., Andrés, F., Arribas, R., Beltrán, J. P., Berbel, A., Blázquez, M. A., Brumos, J., Cañas, L. A., Cercós, M., Colmenero-Flores, J. M., Conesa, A., Estables, B., Gandía, M., García-Martínez, J. L., Gimeno, 
J., Gisbert, A., Gómez, G., González-Candelas, L., Granell, A., Guerri, J., Lafuente, M. T., Madueño, F., Marcos, J. F., Marqués, M. C., Martínez, F., Martínez-Godoy, M. A., Miralles, S., Moreno, P., Navarro, L., Pallás, V., Pérez-Amador, M. A., Pérez-Valle, J., Pons, C., Rodrigo, I., Rodríguez, P. L., Royo, C., Serrano, R., Soler, G., Tadeo, F., Talón, M., Terol, J., Trenor, M., Vaello, L., Vicente, O., Vidal, C., Zacarías, L., and Conejero, V. 2005. Development of a citrus genome-wide EST collection and cDNA microarray as resources for genomic studies. Plant Mol. Biol. 57:375-391.

French, R., and Ahlquist, P. 1988. Characterization and engineering of sequences controlling in vivo synthesis of Brome mosaic virus subgenomic RNA. J. Virol. 62:2411-2420.

Galipienso, L., Navarro, L., Ballester-Olmos, J. F., Pina, J. A., Moreno, P., and Guerri, J. 2000. Host range and symptomatology of a graft-transmissible pathogen causing bud union crease of citrus on trifoliate rootstocks. Plant Pathol. 49:308-314.

Galipienso, L., Vives, M. C., Moreno, P., Milne, R. G., Navarro, L., and Guerri, J. 2001. Partial characterisation of Citrus leaf blotch virus, a new virus from Nagami kumquat. Arch. Virol. 146:357-368.

Galipienso, L., Vives, M. C., Navarro, L., Moreno, P., and Guerri, J. 2004 Detection of Citrus leaf blotch virus using digoxigenin-labeled cDNA probes and RT-PCR. Eur. J. Plant Pathol. 110:175-181.

Gandía, M., Conesa, A., Ancillo, G., Gadea, J., Forment, J., Pallás, V., Flores, R., Duran-Vila, N., Moreno, P., and Guerri, J. 2007. Transcriptional response of Citrus aurantifolia to infection by Citrus tristeza virus. Virology 367:298-306.

Garnsey, S. M., Gonsalves, D., and Purcifull, D. E. 1977. Mechanical transmission of Citrus tristeza virus. Phytopathology 67:965-968.

Gimeno, J., Gadea, J., Forment, J., Pérez-Valle, J., Santiago, J., MartínezGodoy, M., Yenush, L., Bellés, J. M., Brumós, J., Colmenero-Flores, J. M., Talón, M., and Serrano, R. 2009. Shared and novel molecular responses of mandarin to drought. Plant Mol. Biol. 403-420.

Gleba, Y., Klimyuk, V., and Marillonnet, S. 2007. Viral vectors for the expression of proteins in plants. Curr. Opin. Biotechnol. 18:134-141.

Grdzelishvili, V. Z., Chapman, S. N., Dawson, W. O., and Lewandowski, D. J. 2000. Mapping of the Tobacco mosaic virus movement protein and coat protein subgenomic RNA promoters in vivo. Virology 275:177-192.

Guerri, J., Pina, J. A., Vives, M. C., Navarro, L., and Moreno, P. 2004. Seed transmission of Citrus leaf botch virus: Implications in quarantine and certification programs. Plant Dis 88:906-906.

Huerta, L., Forment, J., Gadea, J., Fagoaga, C., Peña, L., Pérez-Amador, M. A., and García-Martínez, J. L. 2008. Gene expression analysis in citrus reveals the role of gibberellins on photosynthesis and stress. Plant Cell Environ. 31:1620-1633.

Igarashi, A., Yamagata, K., Sugai, T., Takahashi, Y., Sugawara, E., Tamura, A., Yaegashi, H., Yamagishi, N., Takahashi, T., Isogai, M., Takahashi, T., and Yoshikawa, N. 2009. Apple latent spherical virus vectors for reliable and effective virus-induced gene silencing among a broad range of plants including tobacco, tomato, Arabidopsis thaliana, cucurbits, and legumes. Virology 386:407-416.

Johnson, J. A., Bragg, J. N., Lawrence, D. M., and Jackson, A. O. 2003. Sequence elements controlling expression of Barley stripe mosaic virus subgenomic RNAs in vivo. Virology 313:66-80.

Koev, G., and Miller, W. A. 2000. A positive-strand RNA virus with three very different subgenomic RNA promoters. J. Virol. 74:5988-5996.

Kumagai, M. H., Donson, J., della-Cioppa, G., Harvey, D., Hanley, K., and Grill, L. K. 1995. Cytoplasmic inhibition of carotenoid biosynthesis with virus-derived RNA. Proc. Natl. Acad. Sci. U.S.A. 92:1679-1683.

Laemmli, U. K. 1970. Cleavage of structural proteins during the assembly of the head of bacteriophage T4. Nature 227:680-685.

Lico, C., Chen, Q., and Santi, L. 2008. Viral vectors for production of recombinant proteins in plants. J. Cell Physiol. 216:366-377.

Livak, K. J., and Schmittgen, T. D. 2001. Analysis of relative gene expression data using real-time quantitative PCR and the $2^{-\Delta \Delta C T}$ method. Methods 25:402-408.

Martelli, G. P., Adams, M. J., Kreuze, J. F., and Dolja, V. V. 2007. Family Flexiviridae: A case study in virion and genome plasticity. Annu. Rev. Phytopathol. 45:73-100.

Navarro, L., Pina, J. A., Ballester-Olmos, J. F., Moreno, P., and Cambra, M. 1984. A new graft transmissible disease found in Nagami kumquat. Pages 234-240 in: Proc. 9th Conf. IOCV. IOCV, Riverside, CA, U.S.A

Pogue, G. P., Lindbo, J. A., Garger, S. J., and Fitzmaurice, W. P. 2002. Making an ally from an enemy: Plant virology and the new agriculture. Annu. Rev. Phytopathol. 40:45-74.
Purkayastha, A., and Dasgupta, I. 2009. Virus-induced gene silencing: A versatile tool for discovery of gene functions in plants. Plant Physiol. Biochem. 47:967-976.

Ratcliff, F., Martin-Hernandez, A. M., and Baulcombe, D. C. 2001. Technical advance: Tobacco rattle virus as a vector for analysis of gene function by silencing. Plant J. 25:237-245.

Renovell, Á., Gago, S., Ruiz-Ruiz, S., Velázquez, K., Navarro, L., Moreno, P., Vives, M. C., and Guerri, J. 2010. Mapping the subgenomic RNA promoter of the Citrus leaf blotch virus coat protein gene by Agrobacterium-mediated inoculation. Virology 406:360-369.

Renovell, A., Vives, M. C., Ruiz-Ruiz, S., Navarro, L., Moreno, P., and Guerri, J. 2012. The Citrus leaf blotch virus movement protein acts as silencing suppressor. Virus Genes 44:131-140.

Robertson, D. 2004. VIGS vectors for gene silencing: Many targets, many tools. Annu. Rev. Plant Biol. 55:495-519.

Ruiz, M. T., Voinnet, O., and Baulcombe, D. C. 1998. Initiation and maintenance of virus-induced gene silencing. Plant Cell 10:937-946.

Ruiz-Ruiz, S., Ambrós, S., del Carman Vives, M., Navarro, L., Moreno, P. and Guerri, J. 2009. Detection and quantitation of Citrus leaf blotch virus by TaqMan real-time RT-PCR. J. Virol. Methods 160:57-62.

Sambrook, J., Fritsch, E. F., and Maniatis, T. 1989. Molecular Cloning: A Laboratory Manual. Cold Spring Harbor Laboratory Press, Cold Spring Harbor, NY, U.S.A.

Shivprasad, S., Pogue, G. P., Lewandowski, D. J., Hidalgo, J., Donson, J., Grill, L. K., and Dawson, W. O. 1999. Heterologous sequences greatly affect foreign gene expression in Tobacco mosaic virus-based vectors. Virology 255:312-323.

Valentine, T. A., Randall, E., Wypijewski, K., Chapman, S., Jones, J., and Oparka, K. J. 2007. Delivery of macromolecules to plant parasitic nematodes using a Tobacco rattle virus vector. Plant Biotechnol. J. $5: 827-834$

Vance, V., and Vaucheret, H. 2001. RNA silencing in plants-defense and counterdefense. Science 292:2277-2280.

Vives, M. C., Galipienso, L., Navarro, L., Moreno, P., and Guerri, J. 2001. The nucleotide sequence and genomic organization of Citrus leaf blotch virus: Candidate type species for a new virus genus. Virology 287:225233.

Vives, M. C., Galipienso, L., Navarro, L., Moreno, P., and Guerri, J. 2002a. Characterization of two kinds of subgenomic RNAs produced by Citrus leaf blotch virus. Virology 295:328-336.

Vives, M. C., Galipienso, L., Navarro, L., Moreno, P., and Guerri, J. 2002b. Citrus leaf blotch virus (CLBV): A new citrus virus associated with bud union crease on trifoliate rootstocks. Pages 205-212 in: Proc. 15th Conf. IOCV. R. G. Milne, N. Duran, and J. V. da Graça, eds. IOCV, Riverside, CA, U.S.A.

Vives, M. C., Galipienso, L., Navarro, L., Moreno, P., and Guerri, J. 2002c. Low genetic variation between isolates of Citrus leaf blotch virus from different host species and of different geographical origins. J. Gen. Virol. 83:2587-2591.

Vives, M. C., Martín, S., Ambrós, S., Renovell, Á., Navarro, L., Pina, J. A. Moreno, P., and Guerri, J. 2008a. Development of a full-genome cDNA clone of Citrus leaf blotch virus and infection of citrus plants. Mol. Plant Pathol. 9:787-797.

Vives, M. C., Moreno, P., Navarro, L., and Guerri, J. 2008b. Citrus leaf blotch virus. Pages 55-67 in: Characterization, Diagnosis and Management of Plant Viruses, Vol. 2. G. P. Rao, A. Myrta, and K. Ling, eds. Studium Press, TX, U.S.A.

Voinnet, O., Pinto, Y. M., and Baulcombe, D. C. 1999. Suppression of gene silencing: A general strategy used by diverse DNA and RNA viruses of plants. Proc. Natl. Acad. Sci. U.S.A. 96:14147-14152

Wang, J., and Simon, A. E. 1997. Analysis of the two subgenomic RNA promoters for Turnip crinkle virus in vivo and in vitro. Virology $232: 174-186$

\section{AUTHOR-RECOMMENDED INTERNET RESOURCES}

Citrus Functional Genomics Project (CFGP) website: bioinfo.ibmcp.upv.es/genomics/cfgpDB

JGI, University of California Regents, and CIG Haploid Clementine Genome webpage: www.citrusgenome.ucr.edu/, http://www.phytozome.net/clementine

JGI, University of California Regents, and CIG Sweet Orange Genome Project webpage: www.phytozome.net/citrus 